\title{
PEMBLOKIRAN BUKU TANAH YANG DILAKUKAN OLEH PIHAK PEMBELI BERDASARKAN AKTA PERJANJIAN PENGIKATAN JUAL BELI
}

\author{
Filzah Aziza Ibrahim, H. Yusriyadi \\ Program Studi Magister Kenotariatan, \\ Fakultas Hukum, Universitas Diponegoro
}

\begin{abstract}
Blocking of a book of certified land begins with a legal relationship between two or more parties involving the certificate as the object of the dispute. Losses experienced by one party in the process of buying and selling led to the application of blocking the book of land certificate to the office. The significance of this writing is to know and analyze the status of the Deed of Sale and Purchase Agreement in the process of blocking the land book by the buyer in the land office and the form of legal protection provided by the land office to the injured party due to buyer blocking based on the Deed of Sale and Purchase Agreement. The result of this research is the position of the sale and purchase binding agreement in the process of blocking the land book conducted by the buyer in the land office only as evidence of actual delivery and juridical delivery between the seller and buyer on the object of sale and purchase, not as an administrative requirement blocking at the land office. The Land Affairs Office provides legal protection by implementing the provisions of Article 125 and Article 126 of the Regulation of the Minister of Agrarian Affairs / Head of the National Land Agency Number 3 of 1997 by limiting the party who wishes to file a blocking request to the land office is a party with a strong legal basis to file the request for blocking in an effort defend that right so that it will not harm the other party.
\end{abstract}

Keywords : Blocking, Deed Of Sale And Purchase Binding Agreement, Legal Protection.

\begin{abstract}
Abstrak
Pemblokiran buku tanah sertipikat diawali oleh suatu hubungan hukum antara dua pihak atau lebih yang melibatkan sertipikat sebagai obyek sengketa.Kerugian yang dialami oleh salah satu pihak dalam proses jual beli memunculkan adanya permohonan pemblokiran buku tanah sertipikat ke kantor. Arti penting dari penulisan ini adalah untuk mengetahui dan menganalisis kedudukan Akta Perjanjian Pengikatan Jual Beli dalam proses pemblokiran buku tanah yang dilakukan pembeli pada kantor pertanahan dan bentuk perlindungan hukum yang diberikan kantor pertanahan kepada pihak yang dirugikan karena pemblokiran oleh pembeli berdasarkan Akta Perjanjian Pengikatan Jual Beli. Hasil dari penelitian ini adalah kedudukan akta perjanjian pengikatan jual beli dalam proses pemblokiran buku tanah yang dilakukan oleh pihak pembeli pada kantor pertanahan hanya sebagai alat bukti telah terjadinya penyerahan secara nyata dan penyerahan yuridis antara penjual dan pembeli atas objek jual beli, bukan sebagai persyaratan administratif permohonan pemblokiran pada kantor pertanahan. Kantor pertanahan memberikan perlindungan hukum dengan melaksanakan ketentuan Pasal 125 dan Pasal 126 Peraturan Menteri
\end{abstract}


Agraria/Kepala Badan Pertanahan Nasional Nomor 3 Tahun 1997 dengan membatasi pihak yang ingin mengajukan permohonan blokir ke kantor pertanahan adalah pihak yang memiliki dasar hukum yang kuat untuk mengajukan permohonan blokir dalam upaya mempertahankan haknya tersebut sehing ga tidak akan merugikan pihak lain.

Kata Kunci : Pemblokiran, Akta Perjanjian Pengikatan Jual Beli, Perlindungan Hukum

\section{A. Pendahuluan}

Keberadaan manusia akan terus tumbuh dan berkembang seiring dengan perkembangan peradaban manusia. Artinya, manusia akan terus mengembangkan keturunannya secara kuantitatif. Perkembangan tersebut berbanding lurus dengan kebutuhan manusia akan tanah sebagai tempat tinggal dan kebutuhan lain yang berkaitan dengan tanah, akan tetapi disisi lain keadaan tanah tidak bertambah, bahkan cenderung terjadi pengurangan karena proses alam.

Kepemilikan atau peralihan tanah oleh individu maupun badan hukum dapat terjadi oleh karena berbagai macam hal. Pasal 37 ayat (1) PP No. 24 Tahun 1997 tentang Pendaftaran Tanah dinyatakan bahwa peralihan hak atas tanah dan hak milik atas satuan rumah susun melalui jual beli, tukar menukar, hibah, pemasukan dalam perusahaan dan perbuatan hukum pemindahan hak lainnya, kecuali pemindahan hak melalui lelang, hanya dapat didaftarkan jika dibuktikan dengan akta yang dibuat oleh PPAT yang berwenang menurut ketentuan peraturan perundang-undangan yang berlaku. Pada penelitian ini peralihan hak atas tanah lebih dititikberatkan peralihan karena jual beli.

Jual beli yaitu peralihan hak sebagai akibat telah dibuatnya suatu perjanjian dengan mana pihak yang satu mengikatkan dirinya untuk menyerahkan suatu kebendaan (tanah) dan pihak lainnya untuk membayar harga yang telah dijanjikan ${ }^{1}$.Pasal 1458 KUHPerdata dinyatakan bahwa jual beli dianggap telah terjadi antara kedua belah pihak, segera setelah orangorang itu mencapai kesepakatan tentang barang tersebut beserta harganya, meskipun barang itu belum diserahkan dan harganya belum dibayar.

\footnotetext{
${ }^{1}$ Waskito \& Hadi Arnowo, Cara Praktis Memahami Bidang Agraria (Pertanahan) (Jakarta: PT. Media Adji Internasional, 2015).
} 
Namun tidak menutup kemungkinan terjadinya jual beli yang tidak langsung tunai atau tidak langsung dilunasi. Hal tersebut dapat disebabkan oleh beberapa hal yang biasanya bersifat administratif seperti misalnya terhadap sertipikat tersebut harus dilakukan perbaikan data mengenai pemekaran wilayah desa atau kecamatan dimana bidang tanah tersebut berada berubah dikarenakan peraturan pemerintahan setempat, proses peralihan hak waris, proses pemisahan terhadap sertipikat induk atau kehendak dari pembeli yang disetujui oleh penjual mengenai pembayaran dilakukan secara bertahap menyesuaikan dengan kondisi keuangan dari pihak pembeli. Untuk tetap dapat melakukan jual beli maka para pihak sepakat bahwa jual beli akan dilakukan setelah pengurusan sertipikat telah selesai, atau setelah harga dibayar lunas dan sebagainya. Untuk menjaga agar kesepakatan itu tetap terlaksana dengan baik sementara persyaratan yang diminta bisa tetap dapat di urus, maka biasanya pihak yang akan melakukan jual beli menuangkan kesepakatan awal tersebut dalam bentuk perjanjian yang kemudian dikenal dengan nama perjanjian pengikatan jual beli. Dalam praktiknya, perjanjian pengikatan jual beli yang dibuat dihadapan notaris lazim disebut dengan akta Perjanjian Pengikatan Jual Beli (PPJB).

Akta Perjanjian Pengikatan Jual Beli (selanjutnya disebut PPJB) adalah akta otentik yang dibuat oleh calon penjual dan calon pembeli suatu tanah/bangunan dihadapan notaris sebagai pengikatan awal sebelum para pihak membuat Akta Jual Beli (AJB) dihadapan Pejabat Pembuat Akta Tanah (PPAT).

Terkait dengan masalah pembuktian, dalam hal terjadi pemblokiran buku tanah sertipikat tentunya Kantor Pertanahan telah memiliki bukti yang kuat untuk mengabulkan atau tidak permohonan pemblokiran buku tanah sertipikat tersebut. Yang menjadi bahan pemikiran yaitu bentuk perlindungan hukum yang dilakukan oleh Kantor Pertanahan dalam menentukan dalam pemblokiran buku tanah sertipikat sehingga tidak merugikan pihak lain.

Pemilik sertipikat dapat menjadi pihak yang dirugikan manakala ada pihak lain yang memohon pemblokiran buku tanah sertipikatnya sedangkan pihak memohon tidak memiliki hak atas seluruh nilai tanah yang terdapat dalam sertipikat yang dimohon pemblokirannya tersebut. Sebaliknya, pihak lain juga 
dapat menjadi pihak yang dirugikan manakala sertipikat tanah dimohon pemblokiran buku tanah oleh pemilik sertipikat itu sendiri dengan tujuan untuk melindungi apa yang menurutnya adalah haknya sedangkan pihak lain juga beranggapan bahwa ia berhak pula atas sebagian dari nilai sertipikat tanah tersebut karena adanya kesepakatan yang dilanggar oleh pemilik sertipikat.

Apabila mengacu pada ketentuan yang ada penetapan pemblokiran buku tanah sertipikat atau disebut juga status quо seharusnya melalui penetapan hakim terlebih dahulu setelah sebelumnya sengketa yang muncul dituangkan dalam sebuah gugatan untuk diajukan ke pengadilan.Kantor pertanahan mencatat perintah status quo tersebut apabila telah menerima penetapan hakim atau putusan pengadilan telah mempunyai kekuatan hukum tetap berikut salinan Berita Acara Eksekusinya. Hal tersebut tertuang dalam Pasal 30 ayat (1) huruf e Peraturan Pemerintah Nomor 24 Tahun 1997, yang menyebutkan bahwa yang data fisik atau data yuridisnya disengketakan dan diajukan ke Pengadilan serta ada perintah untuk status quo atau putusan dari pengadilan, dibukukan dalam buku tanah dengan mengosongkan nama pemegang haknya dan hal-hal lain yang disengketakan serta mencatat di dalamnya adanya sita atau perintah status quo tersebut. Selain itu terdapat juga dalam Pasal 125 ayat (1) Peraturan Menteri Agraria/Kepala Badan Pertanahan Nasional Nomor 3 Tahun 1997, yang menyebutkan bahwa pencatatan perubahan data pendaftaran tanah berdasarkan putusan pengadilan atau penetapan hakim/ketua pengadilan oleh kepala kantor pertanahan dalam daftar buku tanah yang bersangkutan dan daftar umum lainnya dilakukan setelah diterimanya penetapan hakim/ketua pengadilan atau putusan pengadilan yang telah mempunyai kekuatan hukum tetap dan salinan berita acara eksekusi dari panitera pengadilan negeri yang bersangkutan.

Selanjutnya dalam Pasal 125 ayat (2) peraturan yang sama menyebutkan bahwa pihak yang berkepentingan juga dapat meminta untuk dicatat dalam buku tanah pada sertipikat yang akan dijadikan obyek gugatan di pengadilan atau yang diperintahkan untuk di status quo pada kantor pertanahan dengan melampirkan: 
1. Salinan resmi penetapan atau putusan pengadilan yang telah memperoleh kekuatan hukum tetap dan salinan Berita Acara Eksekusi;

2. Sertipikat hak atas tanah atau Hak Milik Atas Satuan Rumah Susun yang bersangkutan;

3. Identitas pemohon.

Pada prakteknya permintaan pemblokiran dalam buku tanah tersebut dapat diajukan oleh pihak yang berkepentingan tanpa melampirkan persyaratan sesuai yang telah ditegaskan dalam Pasal 125 ayat (2) Peraturan Menteri Agraria/Kepala Badan Pertanahan Nasional Nomor 3 Tahun 1997.Seseorang dapat meminta pemblokiran dalam buku tanah sertipikat yang dimaksud dengan hanya menyampaikan alasan serta dokumen pendukung yang menguatkan alasan dan hubungan hukumnya dengan sertipikat tersebut. Hal ini berlangsung sampai sekarang terhadap pemblokiran-pemblokiran tertentu pihak kantor pertanahan seakan membiarkan permohonan pemblokiran yang tanpa alasan yang kuat menurut peraturan perundang-undangan, padahal kepala kantor pertanahan berdasarkan ketentuan Pasal 125 ayat (1) dan (2) Peraturan Menteri Agraria/Kepala Badan Pertanahan Nasional Nomor 3 Tahun 1997 telah cukup mempunyai dasar hukum untuk menolak pemblokiran pada buku tanah sertipikat apabila telah memenuhi ketentuan dalam peraturan tersebut.

Berdasarkan timbulnya permasalahan tersebut maka menarik untuk dilakukan suatu penelitian dengan judul: Pemblokiran Buku Tanah Yang Dilakukan Oleh Pihak Pembeli Berdasarkan Akta Perjanjian Pengikatan Jual Beli.

Berdasarkan latar belakang yang telah diuraikan sebelumnya, maka peneliti mengidentifikasi permasalahan dalam penulisan ini untuk selanjutnya dilakukan pengkajian dalam rangka memberikan pemecahan terhadap permasalahan yang telah dirumuskan yaitu Bagaimana kedudukan Akta Perjanjian Pengikatan Jual Beli dalam proses pemblokiran buku tanah yang dilakukan oleh pihak pembeli pada kantor pertanahan serta Bagaimana bentuk perlindungan hukum yang diberikan oleh kantor pertanahan kepada pihak yang dirugikan karena pemblokiran yang dilakukan oleh pihak pembeli berdasarkan Akta Perjanjian Pengikatan Jual Beli. 


\section{B. Metode Penelitian}

Penelitian hukum merupakan suatu kegiatan ilmiah yang didasarkan pada metode, sistematika, dan pemikiran tertentu, yang bertujuan untuk mempelajari satu atau beberapa gejala hukum tetentu dengan jalan menganalisisnya kecuali itu juga diadakan pelaksanaan yang mendalam terhadap fakta hukum tersebut kemudian mengusahakan suatu pemecahan atas permasalahan-permasalahan yang timbul didalam gejala yang bersangkutan $^{2}$.

Metode pendekatan yang digunakan penulis adalah pendekatan sosio-legal research, yaitu suatu pendekatan alternatif yang menguji studi doktrinal terhadap hukum. Kata "socio" dalam socio-legal studies mencerminkan keterkaitan antar konteks dimana hukum berada (an interface with a context within which law exists). Itulah sebabnya mengapa ketika seorang penulis socio-legal menggunakan teori sosial untuk tujuan analisis, mereka sering tidak sedang bertujuan untuk memberi perhatian pada sosiologi atau ilmu sosial lainnya, melainkan hukum dan studi hukum.

Yuridis empiris merupakan suatu pendekatan yang dilakukan untuk menganalisis tentang sejauh manakah suatu peraturan atau perundangundangan atau hukum yang sedang berlaku secara efektif ${ }^{3}$.

Pendekatan yuridis empiris yang digunakan dalam penelitian ini adalah suatu pendekatan yang digunakan untuk menganalisa ketentuan-ketentuan hukum yang berhubungan dengan pendaftaran tanah pada umumnya, pemblokiran dalam buku tanah sertipikat pada khususnya yang diaktualisasikan dalam pelaksanaan pada Kantor Pertanahan.

\section{Hasil Dan Pembahasan}

1. Kedudukan Akta Perjanjian Pengikatan Jual Beli dalam Proses Pemblokiran Buku Tanah yang Dilakukan oleh Pihak Pembeli pada Kantor Pertanahan.

Perjanjian pengikatan jual beli merupakan perjanjian pendahuluan yang dibuat oleh pihak penjual dan pihak pembeli atas dasar kesepakatan

\footnotetext{
${ }^{2}$ Soerjono Soekanto, Pengantar Penelitian Hukum (Jakarta: UI Pres, 1986).

${ }^{3}$ Rony Hanitijo Soemitro, Metode Penelitian Hukum Dan Jurimetri (Jakarta: Ghalia, 1998).
} 
sebelum jual beli dilaksanakan. Keinginan dan janji-janji dari pihak penjual dan pihak pembeli dituangkan dalam akta perjanjian pengikatan jual beli, hal ini dilakukan untuk mengamankan kepentingan pihak penjual dan pihak pembeli serta bagaimana cara penyelesaian apabila salah satu pihak melakukan wanprestasi. Akta perjanjian pengikatan jual beli ini dilakukan sebelum terjadinya peristiwa hukum jual beli dan dituangkan dalam Akta Jual Beli (AJB).Dengan demikian PPJB tidak dapat disamakan dengan AJB yang merupakan bukti pengalihan hak atas tanah/bangunan dari penjual kepada pembeli.Namun, dengan dibuatkannya PPJB diharapkan secara yuridis dapat memberikan jaminan kepastian hukum dan hak bagi para pihak.

Dalam penelitian ini penulis menemukan suratpermohonan tertanggal 24 Mei 2016 mengenai permohonan blokir buku tanah yang diajukan oleh salah satu kantor hukum. Permohonan tersebut melampirkan Surat Kuasa Khusus dari setidaknya 95 (sembilan puluh lima) orang pihak pembeli atas lebih dari 100 (seratus) unit Apartment yang terletak di jalan Merdeka Bandung dan juga melampirkan copy Akta Perjanjian Pengikatan Jual Beli.

Poin pertama sub a pada surat permohonan tersebut berisi bahwa pihak penjual dalam dalam Akta Perjanjian Pengikatan Jual Beli tersebut adalah PT. PKP. Sedangkan pihak pembeli atas unit apartment dan condotel adalah 95 (sembilan puluh lima) klien dari kantor hukum tersebut yang telah memberikan surat kuasa khusus. Pembelian mana dilakukan secara terang dan tunai, juga atas unit apartment dan condotel tersebut telah dikelola oleh pihak pembeli.Sehingga pihak pembeli menjadi pihak yang berhak dan berkepentingan hukum untuk mengetahui keadaan pendaftaran tanah tersebut. Poin pertama sub b berisi bahwa belum semua surat kuasa dan PPJB atas bidang tanah yang dimaksud dilampirkan dalam surat permohonan dan meminta bahwa hal tersebut tidak menjadi hambatan untuk melakukan permohonan blokir.

Poin kedua berisi bahwa tanah milik bersama tersebut terletak di Jalan Merdeka dan setidaknya terdiri dari 15 (lima belas) sertifikat Hak Guna Bangunan. 
Poin ketiga berisi bahwa atas unit tersebut dilakukan pembayaran dengan sistem terang dan tunai sejak kurang lebih 5 (lima) tahun yang lalu, akan tetapi hingga saat blokir diajukan sertipikat kepemilikan atas unit (strata title) meliputi tanah bersama tersebut belum diberikan pada pihak pembeli, maka PT.PKP telah wanprestasi dan telah menimbulkan kerugian besar bagi pihak pembeli baik moril maupun materil.

Poin keempat berisi bahwa berdasarkan pasal 17 Undang-Undang Nomor 18 tahun 2003 tentang Advokat, bahwa kuasa hukum berhak mengetahui atas pendaftaran tanah atas milik bersama, dengan kata lain Kantor Pertanahan Kota Bandung secara hukum berkewajiban memberi surat keterangan pendaftaran tanah atas tanah milik bersama milik pihak pembeli kepada kuasa hukum selaku advokat.

Poin kelima berisi bahwa dikarenakan kedudukan tanah tersebut diatas menjadi milik pihak pembeli dan hingga saat ini sertipikat belum diberikan kepada pihak pembeli, maka dengan alasan dikhawatirkan adanya pembebanan hak lain atau pengalihan tanah tersebut, maka untuk mencegah terajadinya kerugian yang lebih besar, kuasa hukum memohon agar Kantor Pertanahan memblokir buku tanah terebut sedangkan gugatan di Pengadilan negeri akan segera dilakukan.

Pada praktiknya di kantor pertanahan, permohonan pemblokiran tersebut dikabulkan oleh Kantor Pertanahan Kota Bandung dengan mencatat dalam buku tanah sertipikat induk yang tercatat atas nama PT. PKP sedang dalam pemblokiran yang dimohon oleh pembeli berdasarkan akta PPJB sehingga PT. PKP tidak dapat melakukan penjualan atau pemisahan terhadap sertipikat induk tersebut.

Apabila menunjuk kepada Pasal 125 ayat (2) dan 126 ayat (1) Peraturan Menteri Agraria/Kepala Badan Pertanahan Nasional Nomor 3 Tahun 1997 tentang Ketentuan Pelaksanaan Peraturan Pemerintah Nomor 24 Tahun 1997 tentang Pendaftaran Tanah, pencatatan/pemblokiran buku tanah sertipikat hanya dapat dilakukan oleh pihak yang berkepentingan dengan melampirkan salinan resmi penetapan/putusan pengadilan yang telah memperoleh kekuatan hukum tetap dan salinan Berita Acara Eksekusi atau melampirkan salinan surat gugatan atas suatu hak atas tanah yang akan 
dijadikan obyek di pengadilan. Pada kenyataannya kantor pertanahan tetap mencatatkan blokir buku tanah atas sertipikat induk milik PT.PKP tersebut dengan hanya berdasarkan Akta Perjanjian Pengikatan Jual Beli yang telah dibuat dihadapan notaris sebagai salah satu alat bukti kepemilikan.

Akta Perjanjian Pengikatan Jual Beli mengandung unsur sepakat antara pihak penjual dan pihak pembeli, maka dengan adanya kata sepakat ini lahirlah perikatan, namun hak milik atas objek perikatan yang tercantum di dalam Akta PPJB belum dapat dinyatakan beralih, untuk peralihan tersebut harus diadakan levering atau penyerahan.

Penyerahan atau levering adalah merupakan tindakan atau perbuatan pemindahan hak kepemilikan atas sesuatu barang atau benda dari seseorang kepada orang lain. Namum perlu dipahami bahwa peralihan atau berpindahnya hak atas kekayaan dari seseorang kepada orang lain dapat terjadi dengan titel umum dan titel khusus.

Oleh karena itu, dengan dibuatnya perjanjian pengikatan jual beli saja belum mengakibatkan beralihnya hak milik atas suatu benda dari penjual kepada pembeli. Tahapan ini baru merupakan kesepakatan (konsensual) dan harusdiikuti dengan perjanjian penyerahan (levering), yaitu di tandatanganinya akta jual beli dihadapan Pejabat Pembuat Akta Tanah untuk selanjutnya dilakukan pendaftaran haknya pada kantor pertanahan yang berwenang.

Akta perjanjian pengikatan jual beli dalam permohonan pemblokiran bukan merupakan salah satu unsur untuk memenuhi permohonan pemblokiran oleh pihak yang berkepentingan dikabulkan oleh kantor pertanahan, PPJB hanyalah merupakan alat bukti telah terjadinya penyerahan secara nyata (feitelijke levering) dan penyerahan yuridis (yuridische levering) antara pihak penjual dan pihak pembeli atas objek jual beli untuk selanjutnya dimasukan ke dalam surat gugatan yang menjadi persyaratan administratif permohonan pemblokiran pada kantor pertanahan.

${ }^{4}$ Subekti, Aspek - Aspek Hukum Perikatan Nasional (Bandung: Alumni, 1976). 


\section{Pencatatan/Pemblokiran Buku Tanah Sebagai Bentuk Perlindungan Hukum yang Diberikan oleh Kantor Pertanahan.}

Pencatatan ataupemblokiran buku tanah oleh Kantor Pertanahan atas permohonan pihak yang berkepentingan dengan memenuhi semua persyaratan yang telah diatur oleh Pasal 125 ayat (2) dan 126 ayat (1) Peraturan Menteri Agraria/Kepala Badan Pertanahan Nasional Nomor 3 Tahun 1997 tentang Ketentuan Pelaksanaan Peraturan Pemerintah Nomor 24 Tahun 1997 tentang Pendaftaran Tanah sebagiamana telah di ulas pada Bab III sub A merupakan salah satu bentuk perlindungan hukum yang dilakukan oleh kantor pertanahan kepada pihak yang dirugikan. Berdasarkan kasus posisi yang telah diuraikan, dengan diterimanya permohonan pemblokiran buku tanah oleh pihak pembeli hanya berdasarkan Akta PPJB, maka pihak yang dirugikan adalah bukan hanya pihak pembeli yang mengajukan permohonan pemblokiran buku tanah, melainkan pihak lain yang mempunyai kepentingan dengan sertipikat induk yang tercatat atas nama PT. PKP yaitu PT. PKP sendiri dan pihak lain yang telah melakukan pembayaran cicilan atau uang muka terhadap pembelian apartment dan condotel tersebut, yang menyebabkan dengan status quo sertipikat induk tersebut mereka tidak bisa melakukan proses selanjutnya yaitu pemecahan dan peralihan hak ke atas nama pembeli.

Adanya ketentuan yang memperbolehkan pengajuan pemblokiran dilakukan oleh pihak yang berkepentingan tanpa melalui proses pengadilan dirasakan lebih mudah dan cepat oleh masyarakat sehingga masyarakat lebih memilih cara tersebut dibandingkan melalui gugatan ke pengadilan. Apabila ada pihak yang merasa dirugikan dengan pemberian ijin pemblokiran oleh kantor pertanahan maka pihak tersebut dapat mengajukan keberatan kepada pihak kantor pertanahan, kemudian pihak kantor pertanahan akan berusaha untuk mempertemukan para pihak yang bersangkutan. Jika kesepakatan tidak dapat dihasilkan maka setelah 30 hari kerja blokir tersebut akan hapus dengan sendirinya. Dalam hal ini kantor pertanahan telah berusaha memfasilitasi pihak pemblokir dengan pihak lain yang merasa dirugikan. 
Upaya yang telah dilakukan oleh kantor pertanahan memang bertujuan untuk memberikan perlindungan hukum kepada pihak yang dirugikan, namun apabila payung hukum yang jelas tidak dilaksanakan secara konsisten oleh kantor pertanahan maka akan membuat tujuan kantor pertanahan untuk memberikan perlindungan hukum akan menjadi tidak jelas dan bahkan malahan akan semakin menambah pihak yang dirugikan baik pihak pemblokir maupun pihak terblokir sebagai pemegang hak dalam sertipikat.

\section{SIMPULAN}

Kedudukan akta perjanjian pengikatan jual beli dalam proses pemblokiran buku tanah yang dilakukan oleh pihak pembeli pada kantor pertanahan hanyalah sebagai alat bukti telah terjadinya penyerahan secara nyata dan penyerahan yuridis antara pihak penjual dan pihak pembeli atas objek jual beli, bukan sebagai persyaratan administratif permohonan pemblokiran pada kantor pertanahan.

Kantor pertanahan memberikan perlindungan hukum dengan melaksanakan secara konsistensi ketentuan Pasal 125 dan Pasal 126 Peraturan Menteri Agraria/Kepala Badan Pertanahan Nasional Nomor 3 Tahun 1997 dengan memberi batasan bagi pihak yang ingin mengajukan permohonan blokir ke kantor pertanahan adalah pihak yang memiliki dasar hukum yang kuat untuk mengajukan permohonan blokir dalam upaya mempertahankan haknya tersebut sehingga tidak akan merugikan pihak lain.

\section{DAFTAR PUSTAKA}

Arnowo, Waskito \& Hadi. (2015). Cara Praktis Memahami Bidang Agraria (Pertanahan), Jakarta : PT. Media Adji Internasional

Soekanto, Soerjono (1986). Pengantar Penelitian Hukum . Jakarta: UI Pres, Soemitro, Rony Hanitijo. (1998). Metode Penelitian Hukum Dan Jurimetri, Jakarta: Ghalia,

Subekti (1976) Aspek - Aspek Hukum Perikatan Nasional. Bandung: Alumni 